\title{
Public Policies for Social Innovation in Rural Areas
}

\author{
Nico Polman
}

\subsection{INTRODUCTION}

Social innovation is seen as a way to address different challenges facing stakeholders such as local communities, local third sector agencies and local and regional governments as they address the resolution of social problems and needs, stimulating community wind turbines as a way to deal with climate change and empower rural communities and promote inclusive economic growth (Neumeier 2012; Reynolds et al. 2017; Milley et al. 2018; van Wijk et al. 2018). Social innovation is acknowledged as potential means for development in agriculture and forestry (see for instance Détang-Dessendre et al. 2018; Slee et al. 2018), but also more widely across the whole rural economy. For this chapter we will follow the definition of social innovation as introduced in the Social Innovation in Marginalised Rural Areas (SIMRA) project: "The reconfiguring of social

\section{N. Polman $(\bowtie)$}

Green Economy and Landuse Unit, Wageningen Economic Research, The Hague, The Netherlands

e-mail: nico.polman@wur.nl

(C) The Author(s) 2019

L. Dries et al. (eds.), EU Bioeconomy Economics and Policies:

Volume II, Palgrave Advances in Bioeconomy: Economics and Policies, https://doi.org/10.1007/978-3-030-28642-2_10 
practices, in response to societal challenges, which seeks to enhance outcomes on societal well-being and necessarily includes the engagement of civil society actors" (see Polman et al. 2017).

Public policies for social innovation can seek to stimulate the supply and/or demand for innovations as well as creating an environment in which they can develop. One of the public policy challenges is to identify (potential) innovations to take to a pilot stage and to select those pilots that are best able to improve on existing social practices. Then, selecting those pilots to be scaled up (or out) to achieve systemic change (see European Commission 2013). Investment in regional development can improve the collective asset base from which multiple localities may benefit (Bock 2016).

Social innovations in the European Union can take many forms in both (marginalized) rural areas (see, e.g. SIMRA 2019) and urban areas (e.g. WILCO 2019). In this chapter, in the public policy context, we will focus on social innovations as potentially contributing to development in rural areas (see also Bock 2016; Neumeier 2016). The European Commission has been a "leading proponent of social innovation in the last ten years" (Reynolds et al. 2017). It started in 2010 with the "Innovation Union initiative" as one of the seven flagships of the Europe 2020 strategy for smart, sustainable and inclusive growth. Later followed the "Social Investment Package" (2013) to prioritize social investments in Member States. Both programmes were meant to facilitate inducement, uptake and scaling up of social innovations (see European Commission 2018) through stimulating networking, organizing competitions for best social innovation ideas, funding social innovations, to improve conditions for social innovations, to gather evidence on impact, support incubation and research.

In the current guidelines on "Evaluation of Innovation in Rural Development Programmes" innovations can also be social (see European Commission 2017). The EIP-AGRI may also support social innovations. In 2013 the Commission recognized the role of social innovation to promote the competitiveness of the EU and its regions (European Commission 2013). In the same period the European Bureau of Policy Advisers (BEPA 2010) argued that social innovation represents an important (policy) option to be enhanced at different levels (local, regional, national, European) and across various sectors (public, private, civil). It was argued that regional policy strategies including social innovation are only beginning to emerge (BEPA 2014). As Slee et al. (2018) argue, the realization of local social innovations depends on appropriate institutional architec- 
ture and policy support. Rural development programmes can play an important role in removing barriers and enhancing emerging social innovations (see Slee et al. 2018).

The aim of this chapter is to discuss the relevance of social innovation in the context of rural and agricultural policies. We will not consider "policy as social innovation" (Reynolds et al. 2017) in which policies follow the path of social innovation but recognize the need for policies to support social innovation. In Sect. 10.2, we will position social innovation in the context of other innovations. In Sect. 10.3 we will introduce the concepts of the adaptive cycle and socio-ecological systems as a lens to analyse social innovations in rural areas that differ in the level of (relative) marginalization of socio-ecological systems (SESs; e.g. Nayak et al. 2014; CalloConcha et al. 2014). People in SES can be marginalized due to environmental variables or ecosystem settings (Callo-Concha et al. 2014) and a criterion for ecological marginalization is the status of degradation (Nayak et al. 2014). Applications of the adaptive cycle have been discussed in Meuwissen et al. (2018) for European Union's CAP as a way of exploring the system of farm support and regulatory framework for the farming sector (e.g. environmental directives and the food traceability regulation). The chapter will finish with an evaluation of the potential of social innovations in rural areas as compared to other types of developments. The chapter will end with a discussion/reflection.

\subsection{Social InNOVATION In THE CONTEXT OF INNOVATION}

The understanding of innovations in the context of EU rural development has been rather broad (European Commission 2017). Rural development policy is designed or aims to foster technological, institutional and social innovation. Innovation is seen as an enabling factor for achieving the rural development objectives and priorities, and to address rural challenges. (European Commission 2017). In this Section, we address how social innovation can be classified. OECD/Eurostat (2018) argue that sound measurement of innovation and the use of innovation data can help policy makers to assess the contribution of innovation to their goals and to monitor the effectiveness and efficiency of their policies. OECD/Eurostat (2018) also aim at a better understanding of the impact of innovation on the firm and the market, but also the broader social context in which it operates. 
The European Commission/Eurostat collects data on different types of business innovations in Europe. Data is collected by different regional, national and international institutions at different spatial levels and for different purposes. The Oslo Manual (OECD/European Commission/ Eurostat 2005, 2018) essentially differentiates between two types of innovations:

1. Product innovation: is a new or improved good or service that differs significantly from the firm's previous goods or services and that has been introduced on the market.

2. Business process innovation: is a new or improved business process for one or more business functions that differs significantly from the firm's previous business processes and that has been brought into use by the firm.

Although process and organizational innovations may also develop social capital and, as such, support SI, product innovations are more likely to be directed towards (short term) profit making, although that is not always the case. It is thus not always possible to separate other types of innovation completely from SI because many innovation types include SI elements, whereas SI may also consist of something distinctly social unconnected to product innovation or business processes innovation in the conventional sense. For instance, business process innovations can be beneficial for disadvantaged groups in rural areas without being a SI. Hence, SI would be an additional category as compared to the two types distinguished in the Oslo Manual. Also, the approach of sustainability standard setting has a broader scope than profit making (e.g. Schouten and Glasbergen 2011).

The links between business innovation and SI remain unclear. The total set of innovations can be narrowed down in order to show how SI is separated from other types of innovations. For this purpose, we start from a general definition of innovation as "An innovation is a new or improved product or process (or combination thereof) that differs significantly from the unit's previous products or processes and that has been made available to potential users (product) or brought into use by the unit (process)" (OECD/European Commission/Eurostat 2018). This definition differs from social innovation in the sense that it is not in response to societal challenges or to enhance social well-being. In practice, an organization can introduce more than one type of innovation over the period of data 
collection which makes it more complex to disentangle effect of single innovations (OECD/European Commission/Eurostat 2018). Also, for SI it is important to collect information on multiple innovations as the response can refer either to different innovations or to a combination of more innovation types such as SI and business innovation.

The basic idea is that innovations can occur in every sector of the rural economy. The total set of innovations can be divided into public and private innovations (Fig. 10.1). The classification categories reflect the different fields of study: public innovations versus private innovations. Innovation in the public sector is defined "as the process of generating new ideas and implementing them within the public sector to create value for society, covering new or improved processes (internal focus) and services (external focus)" (see European Commission 2013). Examples are smarter public procurement, creating digital platforms and citizen-centric services. Different actors, including businesses, consumers, public sector and civil society, can drive innovations. Civil society includes the organizations that act in the public's interest but are not motivated by profit or government. Subsets are user-innovations and social innovations. The initiative and drive for carrying out the many different categories of innovation (social innovation, organizational innovation, process innovation, product innovation and market innovation) are not possessed by single actors but are actually the collective product of multiple actors. Obviously, in the case of businesses, they are more than the others aiming for profit (product-, organizational and market innovations), but civil society and consumers can influence also these innovations by establishment of social norms, among others (e.g. eco-labelling).

We do not assume that social innovations and business innovations are always strictly separated because innovations can have more than one focal objective (Pol and Ville 2009) like profit and quality of life. Statistics on SI are lacking, not least because there is such disagreement on definitions. It

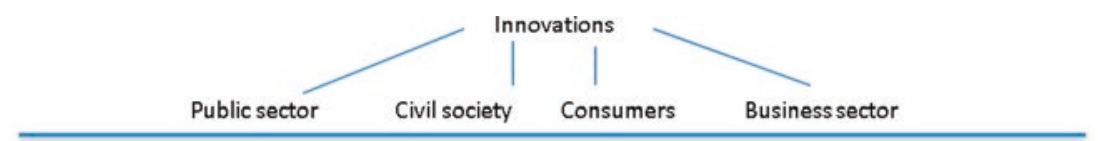

Social innovation; Product innovation; Business process innovation

Fig. 10.1 Classification of innovations following sector of application. (Source: Own presentation) 
will be argued that there is a need for collection of data on SI. This is also important in SIMRA. The Oslo manual states (page 61) that the same issues for measuring innovation outcomes in the government sector also apply to the non-profit institutions serving households (NPISH) implementing social innovation as defined "by their objectives to improve welfare of individuals or communities". NPISHs do not generate income or profit for the units that control or finance them, and they are not part of the government or business sector. Finally, it needs to be kept in mind that social innovation is also often a starting point for creating the social dynamics behind technological innovations (BEPA 2010). Social innovations do not grow in a social vacuum (BEPA 2010) and it complements traditional technological innovation methods (see BEPA 2014).

\subsection{Innovation to Strengthen the Resilience of Socio-ecological Systems in Rural SetTings: The Adaptive Cycle}

Peripheral regions are often regarded as less innovative in comparison to agglomerations because of their often lack of human capital and innovation attitudes (Bock 2012). Many classifications of rurality of regions are available according to the diversity of areas (Price et al. 2017). In practice there is a continuum from urban to rural where also urban and rural areas overlap (Price et al. 2017) and where spatial data alone is insufficient to assess cause-effect relationships of landscape transitions, landscape structure and pattern (Van der Sluis et al. 2018). In this Section, we will focus on the dynamics of rural development of (marginalized) rural areas as it implies that the context for social innovation is continuously changing.

More than a decade ago the concept of the adaptive cycle was introduced in the literature (e.g. Holling 2001; Walker and Meyers 2004), and its use is still primarily descriptive and abstract (see Allen et al. 2014). The adaptive cycle concept is meant to capture the way systems persist and innovate (see Holling 2005). We will apply this concept to investigate dynamics in rural areas in relation to emergence of social innovations. The cycle was originally used to bring social and environmental sciences together, by linking social change with the dynamics of complex ecosystems in response to disturbance and change (Cote and Nightingale 2012). Holling (2001) discusses three core properties of the adaptive cycle: 
1. An inherent potential, a wealth factor, which determines the actual potential of the system, and refers to the accumulated ecological, economic, social and cultural capital, and also potentially future mutations and inventions (Holling and Gunderson 2002). Following Daedlow et al. (2011) this potential of rural areas can for instance be "thought of as the range of accumulated resources such as knowledge, inventions, and skills that are available and accessible."

2. An internal control system, determining the extent to which internal variables and processes are connected, determining the degree to which a system can control its own destiny, which is opposite to being overwhelmed by external drivers. Social connectedness, for instance, may refer to skills, networks of human relationships and mutual trust. In other words, connectedness "reflects the strength of connections that mediate and regulate the influences between inside processes and the outside world - essentially the degree of internal control that a system exerts over external variability" (Holling and Gunderson 2002: 50). If internal control is high, the system is robust to external disturbances. In this respect, it is important to evaluate the possible role of relationships of power influencing resilience (Rawluk and Curtis 2016).

3 . An adaptive capacity, referring to the resilience of the system, which is the actual opposite to vulnerability of the system. When resilience is high, the rural system is wealthy, tightly regulated, and has great ability, available resources and competencies to resist external disturbances, and finally involved social networks can innovate, and communicate, and persist beyond its adaptive and creative points.

Together these properties operate to shape the responses by, for instance, ecosystems, agencies, and/or people to a crisis resulting in four core SES stages or modes of learning and discovery (Holling 2005). These four stages of growth $(\mathrm{r})$, conservation $(\mathrm{K})$, release $(\Omega)$ and reorganization $(\alpha)$ proceed through the system of an adaptive cycle.

In accordance with the four stages, four possible policy leverage points are thus identified in a rural community's adaptive change cycle are highlighted (see Holling 2005). The system slowly moves in a so-called front loop from growth $(\mathrm{r})$ to conservation $(\mathrm{K})$ when ecological and socialeconomic properties increase and get integrated during progression. From $r$ to $\mathrm{K}$ there is thus a gradual accumulation of, for instance, wealth, skills and techniques, strengthening the current system or trajectory of change 
(Biggs et al. 2010). In the K stage, connectedness is high (dependencies) and the system's potential is very high. There is efficiency in resource use, specialization is increasing, and diversity is low. The systems connectedness increases until it eventually gets "over-connected in structural and organizational terms, hence more rigid (less flexible)" (Méndez et al. 2012) and vulnerability to control increases. Human organizations can accumulate rigidities to the point of crisis (e.g. environmental like a forest fire or social such as depopulation) and then attempt to restructure (Holling 2001). Méndez et al. (2012) link its fundamental properties to command-and-control approaches in which, for example, decision making is hierarchically, actor participation is narrowly and passively, power distance and individualism is promoted, and recurrent generation of structural entities. It meets a crisis or collapse, and in a so-called back loop, from release $(\Omega)$ to reorganization $(\alpha)$, it may recover through rapid reorganization; when new combinations encourage innovation and new opportunities. It may also fail for most people, due to unpredictability, uncertainty and vulnerable inherently in the "back loop." As such, the adaptive cycle operates in sequences through time; in the front loop it aims for production and accumulation, whereas in the "back loop" it aims for invention and re-assortment. Rural areas are in different states with overlapping loops with varying degrees of connectivity.

Resilience of this system is explained by a third dimension and appears highest in the move from release $(\Omega)$ to reorganization $(\alpha)$ (Holling $2001)$. Resilience in an ecosystem is high in the reorganization stage $(\alpha)$, but low in the conservation $(\mathrm{K})$ stage when it reaches/approaches crisis/ collapse. With the low resilience in the late K phase, even a small shock can initiate a collapse or release disintegration of the system (low functionality of the system, e.g. an ageing infrastructure and a stagnant rural population). Still, at the reorganization stage $(\alpha)$, social connectedness is low and internal regulation weak. In any time of change, the survivors will benefit from potential gains, while some will lose, and as such, this is also a stage of crisis to some, maybe many. Social resilience is thus weak in both dropping phases, to some from $\alpha$ to $\mathrm{r}$ and to all from $\mathrm{K}$ to $\Omega$.

The adaptive cycle does not imply fixed, regular cycling. A system might remain in one stage for a long time, and the sequence of stages is not fixed (see Meuwissen et al. 2018). The adaptive and evolutionary nature of multiple cycles is nested within each other and across space and time (see Allen et al. 2014). Such a system state is called a panarchy, with the core rationale to attempting to rationalize the interplay between change and 
persistence, between the predictable and the unpredictable. Systems can move back from $\mathrm{K}$ to $\mathrm{r}$, or forth and back from $\alpha$ to $\Omega$. Cycles occur at a number of scales and SESs. The adaptive cycles are interacting across scales (see Walker and Meyers 2004). This has effect on the dynamics of SESs through defining different phases of SES development. A SES can be growing or be in a process of reorganization. The number of levels in a panarchy varies and will be dependent on the dominant scales present in a system (see Allen et al. 2014). In a pine-dominated system, for example, this could be needle, crown, patch and stand with an increasing temporal and spatial scale. The concept of panarchy, representing a nested set of adaptive cycles, is helpful in a number of ways (see Slight et al. 2016):

- It provides a lens to view the reaction of (marginal) rural areas to disturbances (such as hurricanes, forest fires or an economic crisis).

- It describes the ability of a marginal rural area to adapt to disturbances, often improving upon its previous state.

- It provides a framework for understanding the flexibility to change and the capacity to change (as a function of its resources) in rural areas.

Human systems like (marginal) rural areas differ from ecological systems at least in three ways (Holling 2001). First, human foresight and intentionality refer to abilities for predictions and defining scenarios. The human belief in a possible future thus impacts the adaptive cycle, sometimes adversely towards collapses. Second, the adaptive cycle is also impacted by humans having the ability to communicate ideas and experience, and third, human technology has accelerated over the years, with changing the rules and context for the adaptive cycle. The human component is of central importance in the context of social innovation in marginalized rural areas. Human capital as important element of rural capital (see Bosworth and Turner 2018) is often weaker in (marginalized) rural areas as compared to other areas. The success of territorial systems depends also on the "way individuals think and behave" (Capello et al. 2009).

So how does this link with rural areas? While the incremental innovations in marginalized rural areas (Table 10.1) taking place in the front loop fit the purposes of the natural as well as institutional setting, we may reach a point in $\mathrm{K}$ with, for instance, problems due to emigration of young people to metropolitan areas in search for jobs and a different life style. The example is general; in practice (marginal) rural areas differ in oppor- 
Table 10.1 Combining socio-ecological systems (SES) and the adaptive cycle: the case of (marginal) rural areas (MRA)

\begin{tabular}{|c|c|c|c|c|c|}
\hline & & \multicolumn{4}{|c|}{ Adaptive cycle phases } \\
\hline & & Growth (r) & $\begin{array}{l}\text { Conservation } \\
(K)\end{array}$ & Release $(\Omega)$ & $\begin{array}{l}\text { Reorganization } \\
(\alpha)\end{array}$ \\
\hline \multirow[t]{4}{*}{$\begin{array}{l}\text { Socio- } \\
\text { ecological } \\
\text { system } \\
\text { components }\end{array}$} & $\begin{array}{l}\text { Resource } \\
\text { system }\end{array}$ & $\begin{array}{l}\text { The MRA is } \\
\text { providing } \\
\text { resources } \\
\text { itself, } \\
\text { providing } \\
\text { opportunities } \\
\text { for } \\
\text { stakeholders }\end{array}$ & $\begin{array}{l}\text { The MRA } \\
\text { system } \\
\text { reaches its } \\
\text { limits due to } \\
\text { human } \\
\text { activities }\end{array}$ & $\begin{array}{l}\text { The MRA is } \\
\text { due to, for } \\
\text { instance, } \\
\text { leaving } \\
\text { young } \\
\text { people, } \\
\text { climate } \\
\text { change }\end{array}$ & $\begin{array}{l}\text { The MRA } \\
\text { resource system } \\
\text { is in critical } \\
\text { need for } \\
\text { recovery }\end{array}$ \\
\hline & $\begin{array}{l}\text { Resource } \\
\text { unit }\end{array}$ & $\begin{array}{l}\text { The extracted } \\
\text { units can be } \\
\text { extracted } \\
\text { without } \\
\text { problems }\end{array}$ & $\begin{array}{l}\text { The } \\
\text { extracted } \\
\text { units MRA } \\
\text { are about to } \\
\text { reach limits } \\
\text { of recovery }\end{array}$ & $\begin{array}{l}\text { The MRA } \\
\text { does not } \\
\text { recover }\end{array}$ & $\begin{array}{l}\text { The extracted } \\
\text { units are not } \\
\text { operational and } \\
\text { in critical need } \\
\text { for recovery }\end{array}$ \\
\hline & $\begin{array}{l}\text { Governance } \\
\text { system }\end{array}$ & $\begin{array}{l}\text { The } \\
\text { governance } \\
\text { as usual is } \\
\text { based on } \\
\text { institutional } \\
\text { practices } \\
\text { established } \\
\text { for long } \\
\text { period }\end{array}$ & $\begin{array}{l}\text { Governance } \\
\text { as usual, still } \\
\text { hanging on } \\
\text { to how it } \\
\text { used to be }\end{array}$ & $\begin{array}{l}\text { The existing } \\
\text { institutional } \\
\text { system } \\
\text { cannot deal } \\
\text { with the } \\
\text { new } \\
\text { dramatic } \\
\text { challenges } \\
\text { that an } \\
\text { MRA faces }\end{array}$ & $\begin{array}{l}\text { New } \\
\text { governance } \\
\text { structures } \\
\text { emerge that in } \\
\text { ways that can } \\
\text { handle the } \\
\text { dramatic } \\
\text { challenges }\end{array}$ \\
\hline & Actors & $\begin{array}{l}\text { No problem } \\
\text { is observed } \\
\text { and human } \\
\text { acting can } \\
\text { proceed as } \\
\text { usual }\end{array}$ & $\begin{array}{l}\text { Acting as } \\
\text { usual, still } \\
\text { hanging on } \\
\text { to how it } \\
\text { used to be }\end{array}$ & $\begin{array}{l}\text { Human } \\
\text { acting has } \\
\text { dramatic } \\
\text { impacts on } \\
\text { outcomes }\end{array}$ & $\begin{array}{l}\text { Human acting } \\
\text { is challenged } \\
\text { and common } \\
\text { practices must } \\
\text { change, new } \\
\text { power and } \\
\text { poverty } \\
\text { relations } \\
\text { emerge }\end{array}$ \\
\hline
\end{tabular}

Source: Own presentation

Notes: In practice, MRA are diverse where socio-ecological systems and adaptive cycles differ 
tunities and endowments of resources resulting in a more context-specific outcome (e.g. social innovation will depend on the type of area, the socio-economic structures and the phase in which an area is in). Labrianidis (2006) argues that the human factor is of key influence for the exploitation of opportunities and confrontation of challenges in European countryside. In the radical innovation phase in the back loop, new institutional structures are established. For instance, new solutions may reveal: (1) inhabitants from other parts of the country to fill gaps, (2) new attractive opportunities to bring people back or (3) a system which does not see less people in rural areas as a problem because technological innovations can support jobs. Eventually, a drop from $\alpha$ to r, when resilience is low, will bring about new winners and losers.

\subsection{Specific Challenges Observed in Marginalized Rural Areas and Opportunities Associated With Social InNOVATIONS AS CoMpared to Other Types of Developments}

While in the previous section we provide an example of how the adaptive cycle can be used to explain developments in rural areas, in this section the analysis will focus on social innovation which depends on the type of area, the socio-economic structures, the phase in which an area is in, and possible gamechangers like an economic crisis or new inhabitants in the region The evolution of MRAs in Europe shows emergence of a mosaic of opportunities in some place and a decline in others. Frequent features of rural areas are (Bock 2016) population decline and an ageing population, the narrowing down and centralization of services putting remote areas at a disadvantage, the consequences of globalization for networks, growing mobility of capital and people, and ongoing urbanization. The socioeconomic context of rural areas is often characterized by a very limited access to resources (physical, human and financial) (Esparcia 2014) and a less diverse economy (Kratzer and Ammering 2019), although rural areas are not a homogeneous group.

The use of the adaptive cycle and that social innovation is context dependent. (Marginalized) rural areas differ throughout Europe. Social development is context dependent in the sense that MRAs evolve in time. The impact to disturbances will vary in time and will be different depending on the phase an MRA is in. In an exploitation phase the impact of 
disturbances will be limited, whereas in a conservation stage, areas will be more vulnerable, as explained by the commons and MRA examples in the previous section. However, Slight et al. (2016) translated the framework to socio-economic structures. In an exploitation phase, businesses, governance structures and social networks will be younger, the workforce retains and the infrastructure is new. The impact of disturbances will be limited compared to a conservation stage where businesses get older, the workforce is becoming older, infrastructure is ageing and population is stagnant. Different types of rigidities are present which need to be overcome before social innovation can become active. In a release phase, opportunities exist for rapid change in the system and novel recombination of components because human resources and material supplies are "released" into the system (see Slight et al. 2016).

A cycle will not always result in successes to anybody because many experiments and social innovations will fail. SI may have benefits for specific groups at the expense of others implying that the gains are not equally distributed in society. It could be beneficial to stimulate those experiments/innovations where the costs of failure are low. Innovations as developed by clever humans anticipating the future are often local. Others have identified ways to persist within existing structures in MRA, avoiding changes, even when change is needed (see Holling 2005; Scheffer and Westley 2007). Scheffer and Westley (2007) argue that "adult humans apparently have a tendency to stick to a certain mode of behaviour even if it is rationally a bad choice. This lock-in mechanism, caused by apparent self-reinforcing adherence to a mode of behaviour, tends to promote inertia, a lack of responsiveness to changes in the environment." Such a lockin can be caused by different factors like economic (sunk-cost, see Peerlings et al. 2014) and maintaining the status quo or in preventing loss of prestige. Social innovation is path dependent (and contextual) and may well need to overcome established behavioural patterns and particular distributions of power (see, e.g. Moulaert 2009).

\subsection{Reflection on Future and the NeEd For Policy Initiatives}

At the end of the second decade of the twenty-first century, rural policies are on the cusp of change in Europe. Innovation has already been an important element of rural development policies for a long time (BEPA 2014). Social innovations are important for the European Union as a way 
to develop (marginal) rural regions. Social objectives need to balance economic and technical innovations (Détang-Dessendre et al. 2018). Innovation is expected to contribute to achieving the goals of rural development policies. Those policies include the European Innovation Partnership to improve agricultural productivity and to achieve sustainability. Stimulating networking activities like operational groups has been part of rural policies (BEPA 2014) and "effective LEADER groups have often been able to provide the nurture and support to kick-start and empower local activities" (Slee 2019). Also Bosworth et al. (2016) argue that the local scale and the bottom-up character of LEADER is important for mobilizing people in social innovation processes. Social innovations share many characteristics with other innovations and there is a need to evaluate the way they contribute to rural development.

The direct and indirect impact on social practices is often difficult to monitor. Neumeier (2016) argues that it will remain difficult to measure outcomes and performance of social innovation in a predefined or standardized way because many factors are determined by a case-specific interplay factors and shaped by cases. This rural context and capacity of the population is location specific, determined by regional natural and cultural resources, political and socio-economic conditions at different levels.

The adaptive cycle and socio-ecological systems show that the room to manoeuvre of a social innovation actor network (see Neumeier 2016) is dependent on the stage a region or locality is in. In some stages, different types of rigidities need to be overcome before social innovation is likely to change the area for the better to deal with social challenges. In other stages, opportunities exist for rapid reconfigurations of social practices and possible novel recombinations. In those stages, enhancing societal wellbeing can be easier and faster. These factors are open to European policies to stimulate social innovations considering the phase in which a specific rural area is in (context). The adaptive cycle and socio-ecological systems are approaches that can help to evaluate the tools needed to stimulate rural development via social innovation.

Acknowledgement The author is grateful to Maria Nijnik (James Hutton Institute) and Bill Slee (Associate, the Rural Development Company and Emeritus Fellow, the James Hutton Institute) and others of the SIMRA team for their valuable comments and for the support to the project on Social Innovation in Marginalised Rural Areas (SIMRA) provided from the European Union's Horizon 2020 Research and Innovation Programme under Grant Agreement No 677622. He further wants to thank Marijke Dijkshoorn and Katrine Soma (Wageningen Economic Research) for their valuable help in developing initial ideas. 


\section{REFERENCES}

Allen, C.R., D.G. Angeler, A.S. Garmestani, L.H. Gunderson, and C.S. Holling. 2014. Panarchy: Theory and Application. Nebraska Cooperative Fish \& Wildlife Research Unit - Staff Publications. Paper 127.

Biggs, R., F.R. Westley, and S.R. Carpenter. 2010. Navigating the Back Loop: Fostering Social Innovation and Transformation in Ecosystem Management. Ecology and Society 15 (2): 9.

Bock, B.B. 2012. Social Innovation and Sustainability: How to Disentangle the Buzzword and Its Application in the Field of Agriculture and Rural Development. Studies in Agricultural Economics 114 (2): 57-63.

. 2016. Rural Marginalisation and the Role of Social Innovation; A Turn Towards Nexogenous Development and Rural Reconnection. Sociologia Ruralis 56 (4): 552-573.

Bosworth, G., and R. Turner. 2018. Interrogating the Meaning of a Rural Business Through a Rural Capitals Framework. Journal of Rural Studies 60: 1-10.

Bosworth, G., F. Rizzo, D. Marquardt, D. Strijker, T. Haartsen, and A. Thuesen. 2016. Identifying Social Innovations in European Local Rural Development Initiatives. Innovation: The European Journal of Social Science Research 29 (4): 442-461.

Bureau of European Policy Advisors (BEPA). 2010. Empowering People, Driving Change: Social Innovation in the European Union. Brussels: Bureau of European Policy Advisors.

- 2014. Social Innovation; A Decade of Changes. Brussels: Bureau of European Policy Advisors.

Callo-Concha, D., J.H. Sommer, J. Kleemann, F. Gatzweiler, and M. Denich. 2014. Marginality from a Socio-ecological Perspective. In Marginality; Addressing the Nexus of Poverty, Exclusion and Ecology, ed. J. von Braun and F.W. Gatzweiler, 57-65. Dordrecht: Springer.

Capello, R., A. Caragliu, and P. Nijkamp. 2009. Territorial Capital and Regional Growth: Increasing Returns in Cognitive Knowledge Use. Amsterdam: Tinbergen Institute Discussion Papers. TI 2009-059/3.

Cote, M., and A.J. Nightingale. 2012. Resilience Thinking Meets Social Theory: Situating Social Change in Socio-Ecological Systems (SES) Research. Progress in Human Geography 36 (4): 475-489.

Daedlow, K., V. Beckmann, and R. Arlinghaus. 2011. Assessing an Adaptive Cycle in a Social System Under External Pressure to Change: The Importance of Intergroup Relations in Recreational Fisheries Governance. Ecology and Society $16(2): 3$.

Détang-Dessendre, C., F. Geerling-Eiff, H. Guyomard, and K. Poppe. 2018. EU Agriculture and Innovation: What Is the Role for the CAP. Den Haag: INRA and WUR. 
Esparcia, J. 2014. Innovation and Networks in Rural Areas. An Analysis from European Innovative Projects. Journal of Rural Studies 34: 1-14.

European Commission. 2013. Guide to Social Innovation. Brussels: Regional and Urban Policy Publications, Office of the European Union.

- 2017. Evaluation of innovation in rural development programmes 20142020, Directorate-General for Agriculture and Rural Development - Unit C.4: Guidelines, Brussels.

- 2018. Social Innovation. http://ec.europa.eu/growth/industry/innovation/policy/social_en. Accessed 5 Apr 2019.

Holling, C.S. 2001. Understanding the Complexity of Economic, Ecological, and Social Systems. Ecosystems 4 (5): 390-405.

- 2005. From Complex Regions to Complex Worlds. Minnesota Journal of Law, Science \& Technology 7: 1-20.

Holling, C.S., and L. Gunderson. 2002. Resilience and Adaptive Cycles. In Understanding Transformation in Human and Natural Systems, ed. L. Gunderson and C.S. Holling, 25-62. Washington, DC: Island Press.

Kratzer, A., and U. Ammeringn. 2019. Rural Innovations in Biosphere Reserves-A Social Network Approach. Journal of Rural Studies 71: 144-155.

Labrianidis, L. 2006. Human Capital as the Critical Factor for the Development of Europe's Rural Peripheral Areas. In The New European Rurality: Strategies for Small Firms, ed. T. de Noronha Vaz, E.J. Morgan, and P. Nijkamp, 41-59. Abingdon: Routledge.

Méndez, P.F., N. Isendahl, J.M. Amezaga, and L. Santamaría. 2012. Facilitating Transitional Processes in Rigid Institutional Regimes for Water Management and Wetland Conservation: Experience from the Guadalquivir Estuary. Ecology and Society 17 (1): 26.

Meuwissen, M.P., W.H. Paas, T. Slijper, I. Coopmans, A. Ciechomska, E. Lievens, J. Deckers, et al. 2018. Report on Resilience Framework for EU Agriculture. Wageningen: Wageningen University \& Research: H2020 SureFarm, WorkPackage 1 .

Milley, P., B. Szijarto, K. Svensson, and J.B. Cousins. 2018. The Evaluation of Social Innovation: A Review and Integration of the Current Empirical Knowledge Base. Evaluation 24 (2): 237-258.

Moulaert, F. 2009. Social Innovation: Institutionally Embedded, Territorially (re) Produced. In Haddock Social Innovation and Territorial Development, ed. D. MacCallum, F. Moulaert, J. Hillier, and S.V. Haddock, 27-40. Abingdon: Routledge.

Nayak, P.K., L.E. Oliveira, and F. Berkes. 2014. Resource Degradation, Marginalization, and Poverty in Small-Scale Fisheries: Threats to SocialEcological Resilience in India and Brazil. Ecology and Society 19 (2): 73.

Neumeier, S. 2012. Why do Social Innovations in Rural Development Matter and Should They be Considered More Seriously in Rural Development Research?- 
Proposal for a Stronger Focus on Social Innovations in Rural Development Research. Sociologia Ruralis 52 (1): 48-69.

- 2016. Social Innovation in Rural Development: Identifying the Key Factors of Success. The Geographical Journal 183 (1): 34-46.

OECD/Eurostat. 2005. Oslo Manual 2005: Guidelines for Collecting, Reporting and Using Data on Innovation, 3rd Edition, The Measurement of Scientific, Technological and Innovation Activities. Paris/Luxembourg: OECD Publishing/Eurostat.

- 2018. Oslo Manual 2018: Guidelines for Collecting, Reporting and Using Data on Innovation, 4th Edition, The Measurement of Scientific, Technological and Innovation Activities. Paris/Luxembourg: OECD Publishing/Eurostat.

Peerlings, J., N. Polman, and L. Dries. 2014. Self-Reported Resilience of European Farms with and Without the CAP. Journal of Agricultural Economics 65 (3): 722-738.

Pol, E., and S. Ville. 2009. Social Innovation: Buzz Word or Enduring Term? The Journal of Socio-Economics 38 (6): 878-885.

Polman, N.B.P., B. Slee, T. Kluvankova, M.W.C. Dijkshoorn-Dekker, M. Nijnik, V. Gežik, K. Soma. 2017. Classification of Social Innovations for Marginalized Rural Areas. SIMRA Project Report. http://www.simra-h2020.eu/wpcontent/uploads/2017/09/D2.1-Classification-of-SI-for-MRAs-in-thetarget-region.pdf

Price, M., D. Miller, M. McKeen, W. Slee, and M. Nijnik. 2017. Categorisation of Marginalised Rural Areas (MRAs), Deliverable 3.1, Social Innovation in Marginalised Rural Areas (SIMRA). Report to the European Commission, 57.

Rawluk, A., and A. Curtis. 2016. Reconciling Contradictory Narratives of Landscape Change Using the Adaptive Cycle: A Case Study from Southeastern Australia. Ecology and Society 21 (1): 17.

Reynolds, S., M. Gabriel, and C. Heales. 2017. Social Innovation Policy in Europe: Where Next? Social Innovation Community. D5.3: Annual State of the Union Report - Part 1, Nesta and Young Foundation. https://www.siceurope.eu/ sites/default/files/field/attachment/social_innovation_policy_in_europe_-_ where_next.pdf

Scheffer, M., and F.R. Westley. 2007. The Evolutionary Basis of Rigidity: Locks in Cells, Minds, and Society. Ecology and Society 12 (2): 36.

Schouten, G., and P. Glasbergen. 2011. Creating Legitimacy in Global Private Governance: The Case of the Roundtable on Sustainable Palm Oil. Ecological Economics 70 (11): 1891-1899.

SIMRA. 2019. Welcome to SIMRA. http://www.simra-h2020.eu/. Accessed 5 Apr 2019.

Slee, B.M. 2019. Smart Villages and Social Innovation: The SIMRA Project. https://www.scitecheuropa.eu/smart-villages-social-innovation/94909/. Accessed 31 May 2019. 
Slee, B., M. Clotteau, R. Lukesch, G. Weiss, and A. Ludvig. 2018. How Can Social Innovation Support the Future of Food and Farming? Policy Brief, Social Innovation in Marginalised Rural Areas (SIMRA). http://www.simra-h2020. eu/wp-content/uploads/2018/02/SIMRA_Final_policy_brief.pdf. Accessed 31 May 2019.

Slight, P., M. Adams, and K. Sherren. 2016. Policy Support for Rural Economic Development Based on Holling's Ecological Concept of Panarchy. International Journal of Sustainable Development \& World Ecology 23 (1): 1-14.

van der Sluis, T., B. Pedroli, P. Frederiksen, S.B. Kristensen, A.G. Busck, V. Pavlis, and G.L. Cosor. 2018. The Impact of European Landscape Transitions on the Provision of Landscape Services: An Explorative Study Using Six Cases of Rural Land Change. Landscape Ecology 34 (2): 1-17.

van Wijk, J., C. Zietsma, S. Dorado, F.G. de Bakker, and I. Martí. 2018. Social Innovation: Integrating Micro, Meso, and Macro Level Insights from Institutional Theory. Business \& Society 58: 887. https://doi.org/10.1177/ 0007650318789104.

Walker, B., and J.A. Meyers. 2004. Thresholds in Ecological and Social-Ecological Systems: A Developing Database. Ecology and Society 9 (2): 3.

WILCO. 2019. http://www.wilcoproject.eu/. Accessed 5 Apr 2019. 